\title{
The Determinants of Banks' Capital Adequacy Ratio: Some Evidence from South Eastern European Countries
}

\author{
${ }^{1}$ Rafet Aktas*, ${ }^{2}$ Suleyman Acikalin, ${ }^{1}$ Bilge Bakin, ${ }^{3}$ Gokhan Celik \\ 1Yildirim Beyazit University, Ankara, Turkey \\ ${ }^{2}$ Hitit University, Corum, Turkey \\ ${ }^{3}$ Central Bank of the Republic of Turkey, Turkey \\ *raktas@ybu.edu.tr
}

\begin{abstract}
The legal authorities set the minimum capital level for the banks. Recent studies have shown that variables used to explain capital structure of non financial firms, such as size, profit, leverage, liquidity and risk, could also be helpful in understanding banks' capital structure. This paper aims to evaluate the impact of bank-dimensional and environmental factors on bank's capital adequacy ratio in South Eastern European (SEE) region. Size, profitability (ROA), leverage, liquidity, net interest margin (NIM), and risk are used as bank-dimensional explanatory variables in a feasible GLS regression model. On the other hand, economic growth rate, inflation, real interest rate, Eurozone stock market volatility index, deposit insurance coverage, and governance indicator are added to the original model to control for environmental factors. Annual data from 71 commercial banks belong to 10 different countries in SEE region for the period of 2007 - 2012 is used. This region mainly consists of the "transition economies" which are still experiencing the difficulties of turning into efficient market economies with high economic potentials. The results of our study show that among the bank dimensional explanatory variables size, ROA, leverage, liquidity, net interest margin and risk have statistically significant effects in determining CAR for the banks in the region. Among the environmental factors, economic growth rate, Eurozone stock market volatility index, deposit insurance coverage, and governance have statistically significant effects in determining CAR for the banks in the SEE region.
\end{abstract}

Keywords: Banks, Capital Adequacy Ratio (CAR), Feasible GLS, South Eastern European (SEE) region

\section{Introduction}

The capital structure refers to the mixture of debt and equity financing of total assets. The topic draw attention from both theoretical and applied researches since it is related to a critical problem of firm's value maximization in finance literature. It is possible to start the discussion about the issue with the well-known Modigliani-Miller (1958) article. Modigliani and Miller (1958) dealt with the issue of "cost of capital" and showed that under restrictive assumptions it does not matter whether a firm finances itself with a debt or equity financing. Since Modigliani and Miller (1958), there have been various studies on the topic of optimal capital structure. Studies on banks' capital structure and its determinants initially concentrated on bank specific characteristics such as size, risk, liquidity, profitability and leverage. Some of these studies concluded that banks' decisions on the subject do not show a significant difference from the concerns of the non-financial institutions (Gropp \& Heider, 2010; Juca et al., 2012). Other studies determined that there are factors, such as competition and other market related variables explaining banks' excess capital holdings above the legal level (Schaek \& Cihak, 2012). Later, environmental factors such as GDP growth rate, inflation rate, stock market index, governance, coverage ratio, and etc. are added to the analysis (Mili et al., 2014; Baltaci \& Ayaydin, 2014; Ogere et al., 2013; Williams, 2011).

Because of the nature of the business they conduct and also their role as intermediaries in economy, banks should be considered separately in the context of capital structure concerns. Banks may tend to hold less than optimal capital relative to their riskiness and the threat of bank default. Hence, this situation requires capital regulation for banks by authorities (Rime, 2001). The common goal of regulation is to stabilize the banking sector through reducing risk and increasing the reliability of the system by providing adequate supply of capital. This, in turn, would help banking system to continue its intermediation role without interruptions. However, the latest global financial crisis of 2008 indicated that there is significant discrepancy between the market and the regulatory measures of risk and capital adequacy (Hasan et al., 2015; Acharya et al., 2012). In this study, we investigate the determinants of banks' CAR in South Eastern European (SEE) region. Financial integration of transition economies in SEE 
started back in the second half of 1990s. Once the importance of banking sector in economic development in SEE region is recognized, focus turned into creating an effective financial intermediation process (Staikouras et al., 2008; Bonin, 2004). The developments in the banking sector of 10 large Central and Eastern European countries from 1999 to 2005 are outlined by Barisitz (2005). This report shows that the banks in both regions went through important structural and regulatory changes and the relatively low consumption of banking services in these countries indicate that there exist a big potential to grow in the banking sector in those areas. The competitive structure of banks in the South Eastern Europe is regarded as monopolistically competitive (Mamatzakis et al., 2005). The importance of completion of economy wide reforms and restructuring in the banking sector by the transition economies in the SEE region for their growth and also in terms of the relationship with EU is explained in detail by Stubos and Tsikrips (2005). These studies indicate that developments in the region and its banking sector would be a fruitful study area for researchers of the banking literature.

The purpose of the study is twofold. First, we would like to determine the effects of bank dimensional factors on the CAR of banks in SEE region. The contribution of this paper is to show that most of the bank dimensional variables that were found statistically significant in capital decision of banks in developed economies are also significant in explaining the capital decision of banks in the SEE region. Second, we would like to see the effects of environmental factors on this decision. The inclusions of these factors, which provide additional economic and regulatory information for the ten countries in the region, show us that capital adequacy is not just determined by bank specific factors alone. There are five sections in this study. The second section is a review of the literature on the topic of capital structure. The data is given in section 3 . The methodology and main findings are given in section 4 . Next, concluding remarks are presented in section 5 .

\section{Literature Review}

The seminal work of Modigliani and Miller (1958) showed that under the restrictive assumptions of perfect capital markets with no taxes, there would not be any difference between debt and equity financing in value maximization of any firm under the same risk class. However, Modigliani and Miller (1963) showed that under the existence of corporate taxes, the value of the firm would increase with the use of debt financing because of tax deductibility of interest expenses. Many researchers studied the issue of optimal capital structure under various assumptions following Modigliani and Miller $(1958,1963)$, and a number of finance theory on the subject were developed. Two of these traditional theories about the capital structure issue are the trade-off theory and the pecking order theory. According to the trade-off theory an optimal capital structure is achieved when the benefits of debt financing is equalized with the cost of bankruptcy costs (Frank \& Goyal, 2005; Kim \& Berger, 2008; Octavia \& Brown, 2009). The pecking order theory, on the other hand, argues that firms prefer using retained earnings as the first option to finance new investment opportunities, they prefer using debt financing as the second option and using equity financing as the last resort (Frank \& Goyal, 2005; Fauzi et al., 2013). In other words, the pecking order theory is argued that due to informational asymmetry, the retained earnings are preferred to debt and debt is preferred to equity in financing new investment opportunities (Frank \& Goyal, 2005).

Concerns on capital structure of non-financial and financial institution show some differences. Large firms in the non-financial sectors prefer higher debt ratio as their bankruptcy risk is low and the taxshield of debt financing result with higher profit margins relative to the small ones. This situation is quite different for banks and other financial institutions. Since deposits are debts for the banks, generally they do not use other forms of debt in their capital structure (Nguyen \& Kayani, 2013). Studies on financial institutions such as banks up until the last decade, accepted the idea that capital structure of banks mainly determined by the regulations. In order to increase the reliability of the international banking system, the Bank for International Settlements (BIS) defines a minimum level of capital, which is $8 \%$ on total assets. Once this idea is accepted there are not many reasons to study the factors affecting the capital structure of banks. However, developments and studies after 2000 showed that this is not the case. For example, Schaek and Cihak (2012) interested in the following question "why do banks maintain capital levels above regulatory requirements?" Data covering 2600 banks from 10 European countries is used to test the question whether competition leads to a higher capital ratio. The results supported the theories stating that the competition increases capital holdings. Juca et al. (2012b) stated that the largest twenty banks in Brazil hold about 18\%, and the largest twenty world banks hold 14\% minimum level of capital, even though Basel requirement is only $8 \%$. 
Gropp and Heider (2010) suggested that there are considerable similarities between banks' and nonfinancial firms' capital structure. A similar conclusion is reached by Juca et al., (2012a).This study was conducted on 30 North American banks for the period of 2007-2010 and concluded that the standard determinants explaining the capital structure of non-financial firms also have a significant power in explaining the banks' capital structure (Juca, 2012a). Sharpe (1995) with data on Australian trading banks for the period of 1967-1988 found statistical evidence supporting Myer's Pecking Order Theory in the presence of transaction costs and asymmetric information. Altunbas et al. (2007) studied the relationship between capital, risk, and efficiency for large European banks for the period of 1992-2000. A positive relationship between risk and capital ratio is determined. Baltaci and Ayaydin (2014) suggested that the capital structures of financial and non-financial firms are determined by the same factors based on data from Turkish banking sector for the period of 2002-2012. Another study on Turkish banking sector covering the period of 2006-2010 concluded that loans, return on equity and leverage have a negative effect on capital adequacy ratio (CAR) while loan loss reserve and return on assets have positive effects (Buyuksalvarci \& Abdioglu, 2011). Octavia and Brown (2009) studied whether the standard determinants of capital structure is applicable in case of banks in developing countries. 56 banks from 10 developing countries are used in this study. They concluded that there is a little evidence that macroeconomic factors are important in determining the capital structure in those banks (Octavia \& Brown, 2009). Amidu (2007) concluded that profitability, corporate tax, growth, asset structure, and size influence banks' capital structure decision. Mili et al. (2014) focused on the bank-dimensional determinants but also considered the impact of factors such as economic growth and real interest rate.

Additionally, Ogere et al. (2013) and Williams (2011) investigate the relationship between inflation and capital adequacy in Nigeria. Furthermore, Gropp and Heider (2010) are also interested in the impact of deposit insurance coverage on bank capital structure as well as the impacts of bank-characteristics. On the other hand, a number of studies are added to the literature questioning the determinants of the capital structure of banking sector in developing economies during the last couple of years (Amjad \& Tufail, 2013; Saeed et al., 2013; Romdhane 2012; Bokhari et al., 2012; Mathuva 2009; Asarkaya \& Ozcan 2007). The determinants of capital structure have been studied since 1950s in the developed countries. The research on the same topic for the developing economies gathered momentum only after 2000s. Even though this is the situation, to the authors' knowledge, there is no previous study investigating the determinants of banks' CAR in the SEE Countries. Moreover, besides bank dimensional variables and economic variables such as economic growth, inflation, real interest rate, and deposit insurance coverage, we also consider the effects of environmental variables such as Eurozone stock market volatility index and governance indicator on CAR in the SEE region in our study.

Data: We have used 71 commercial banks from 10 different countries in SEE region, namely; Albania, Bosnia, Bulgaria, Croatia, Greece, Macedonia, Montenegro, Romania, Serbia and Slovenia. The number of banks according to countries is given in Table 1 :

Table 1: Number of banks in the countries

\begin{tabular}{ll}
\hline Countries & Number of Banks \\
\hline Albania & 7 \\
Bosnia & 7 \\
Bulgaria & 8 \\
Croatia & 8 \\
Greece & 4 \\
Macedonia & 9 \\
Montenegro & 3 \\
Romania & 8 \\
Serbia & 4 \\
Slovenia & 13 \\
Total & 71 \\
\hline
\end{tabular}

The study covers the period of 2007-2012 and annual data are used. Since this study aims to investigate the determinants of capital adequacy of banks in SEE region, the dependent variable is capital adequacy ratio (CAR). The bank-dimensional independent variables are identified as bank size, profitability, leverage, liquidity, net interest margin and bank risk while environmental independent variables are determined as economic growth, inflation, real interest rate, Eurozone stock market volatility index, deposit insurance coverage ratio, and governance indicator. Capital adequacy ratio (CAR) is the ratio of an 
eligible regulatory capital (i.e. the total of Tier 1 and Tier 2) to its risk weighted assets (Apostolic et al., 2009). We use the disclosed CAR value of each bank in the database. Bank size (SIZE) is one of the most preferable determinants in the existing literature (Juca et al., 2012a; Gropp \& Heider, 2010; Octavia \& Brown, 2009). In some studies, the impact of size on banks' capital structure is found as negative, whereas some other studies found this impact as positive. In this study, it is measured as the natural logarithm of total assets of banks. Profitability is measured by the ratio of return on assets (ROA) as in the studies of Allen et al. (2013), Okuyan (2013) and Gropp and Heider (2010). Leverage (LEV) is another variable affecting the capital structure of banks. In this study, it is taken as the ratio of total liabilities to total equity. The liquidity (LQDT) is taken as the ratio of liquid assets to deposits and money market funds. Net interest margin (NIM) is taken as a ratio of net interest income to average total assets (Buyuksalvarci \& Abdioglu, 2011; Mili et al., 2014). The impact of (NIM) on CAR can be detected as either negative or positive. The final bank-dimensional independent variable is the bank risk (RISK). It is measured as the ratio of risk weighted assets to total assets as cited in Allen et al., (2013) and Bokhari et al. (2012). The risk factor may have either negative or positive impact on banks' CAR (Romdhane, 2012; Juca et al., 2012a; Octavia \& Brown, 2009). All the bank-dimensional variables are obtained from the database of The Bankers Almanac.

Besides bank-dimensional determinants, we also consider the impacts of environmental factors on CAR as controlling variables. Economic growth (GDP_G) is taken as the change in real gross domestic product in years (Octavia \& Brown, 2009; Asarkaya \& Ozcan, 2007). The source of economic growth data is Bloomberg. Inflation (CPI) is also considered as an economic factor affecting capital adequacy (Ogere et al., 2013; William, 2011). The change in consumer price index of each country is used to measure inflation. The data is retrieved from database of International Monetary Fund (IMF). Real interest rate (RIR) is another variable used in the study as employed in the study of Mili et al., (2014). All the real interest rates are obtained from the database of World Bank except Greece and Slovenia. RIR for Greece is calculated as the difference between its 10 -year generic government bond yield and realized inflation rate whereas RIR for Slovenia is calculated from the difference between the long-term bond yield retrieved from OECD and realized inflation rate. Eurozone stock market volatility index (EURO_VOL) is another independent factor since the time line of the study covers the years in which "Eurozone Crisis" is realized. During the crisis, the volatility on the stock market is expected to surge. Therefore, the implied volatility based on the EURO STOXX50 Index options, obtained from Bloomberg, is used as a proxy for the tension of the market. Coverage ratio (COV) is the ratio of coverage limit, known as the deposit insurance, to GDP per capita. Coverage limits are obtained from World Bank (Demirguc-Kunt et al., 2014). The reported coverage limits in local currencies are converted into U.S. Dollar, and normalized by each country's GDP per capita acquired from World Bank database. The final independent factor is governance (GOV). World Governance Indicators consists of 6 basic elements; "Voice and Accountability, Political Stability and Absence of Violence/Terrorism, Government Effectiveness, Regulatory Quality, Rule of Law, and Control of Corruption" (Kaufmann et al., 2010). We take the "Rule of Law" indicator which is the principle that governs the degree to which actors are subjected to the premises of law and their obedience to societal rules, specifically the contract enforcement, property rights, the police and the courts. This indicator, ranging between -2.5 and 2.5, is obtained from the Worldwide Governance Indicators. The details of descriptive statistics of the dependent and independent variables are given as Table 2.

Table2: The descriptive statistics of the dependent and independent variables

\begin{tabular}{|c|c|c|c|c|c|}
\hline Variable & & Min & Max & Mean & Standard Deviation \\
\hline Capital Adequacy Ratio (CAR) & & -0.05 & 0.454 & 0.156 & 0.049 \\
\hline Bank Size (SIZE) & & 4.543 & 11.701 & 7.490 & 1.559 \\
\hline Return on Assets (ROA) & & -0.124 & 0.154 & 0.007 & 0.020 \\
\hline Leverage (LEV) & & -104.287 & 92.363 & 8.837 & 9.164 \\
\hline Liquidity (LQDT) & & 0.003 & 0.781 & 0.167 & 0.112 \\
\hline Net Interest Margin (NIM) & & 0.002 & 0.116 & 0.037 & 0.016 \\
\hline Bank Risk (RISK) & & 0.086 & 1.462 & 0.769 & 0.135 \\
\hline Economic Growth (GDP_G) & & -7.797 & 10.7 & 1.184 & 4.184 \\
\hline Inflation (CPI) & & -0.740 & 12.411 & 3.853 & 2.690 \\
\hline $\begin{array}{l}\text { Real Interest Rate (RIR) } \\
\text { Eurozone } \quad \text { Stock Market }\end{array}$ & Volatility & $\begin{array}{l}-3.119 \\
19.720\end{array}$ & $\begin{array}{l}27.432 \\
33.729\end{array}$ & $\begin{array}{l}5.545 \\
28.049\end{array}$ & $\begin{array}{l}4.212 \\
5.020\end{array}$ \\
\hline
\end{tabular}




\begin{tabular}{lllll}
\hline (EURO_VOL) & & & & \\
Coverage Ratio (COV) & 0.303 & 9.116 & 2.749 & 2.456 \\
Governance (GOV) & -0.699 & 1.058 & 0.063 & 0.524 \\
\hline
\end{tabular}

\section{Methodology and Empirical Results}

In this study, we are mainly interested in determining factors affecting the CAR of banks of the SEE region countries. Thus, our basic model is constructed as in Equation 1. Equation 1 uses only bank dimensional factors as explanatory variables affecting CAR decision. However, we also add some other variables at country or zone level into our first model in order to control the environmental factors as given in Equation 2.

$$
\begin{aligned}
& C A R_{i t}=\alpha_{i}+\beta_{1} S I Z E_{i t}+\beta_{2} R O A_{i t}+\beta_{3} L E V_{i t}+\beta_{4} L Q D T_{i t}+\beta_{5} N I M_{i t}+\beta_{6} R I S K_{i t}+u_{i t}(1) \\
& C A R_{i t}=\alpha_{i}+\beta_{1} S I Z E_{i t}+\beta_{2} R O A_{i t}+\beta_{3} L E V_{i t}+\beta_{4} L Q D T_{i t}+\beta_{5} N I M_{i t}+\beta_{6} R I S K_{i t}+\beta_{7} G D P_{-} G_{i t}+\beta_{8} C P I_{i t}+ \\
& \beta_{9} R I R_{i t}+\beta_{10} E U R O{ }_{-} O L_{i t}+\beta_{11} \operatorname{COV}_{i t}+\beta_{12} G O V_{i t}+v_{i t}(2)
\end{aligned}
$$

In the given models, $\alpha_{i}$ implies the unobservable effects of banks (i.e. individual effect). Firstly, we try to specify our basic model whether it is a fixed effect or a pooled least square model. The null hypothesis, $\mathrm{H}_{0}$ : $\alpha_{\mathrm{i}}=0$ and the alternative hypothesis, $\mathrm{H}_{\mathrm{a}}: \alpha_{\mathrm{i}} \neq 0$ are constructed under F-test with (N-1, NT-N-k) degrees of freedom. F-test statistics $(70,349)$ is 7.37 with a Prob. value of 0.000 enables us to reject the null hypothesis implying a fixed effect model is more appropriate (Baltagi, 2005). Secondly, we also test whether our model is random effect model or pooled least square model. This specification is tested by Lagrange Multiplier (LM) Test of Breusch and Pagan (1980). If the null hypothesis, $\mathrm{H}_{0}: \sigma_{\alpha i}^{2}=0$, is rejected then random effect model is decided to be appropriate (Baltagi, 2005). The calculated chi-square test statistics with 1 degree of freedom is 206.31 with Prob. Value of 0.000 , which indicates the rejection of null hypothesis. Hence, random effect model could also be constructed. According to specification test results, an individual effect is discovered; however it is required to decide whether to construct the model as fixed or random effect model. For this purpose, a well-known specification test Hausman (1978) having chi-square distribution with a number of regressors $(\mathrm{k})$ degrees of freedom is conducted (Baltagi, 2005). The correlation between the unobservable effects $\left(\alpha_{i}\right)$ and regressors $\left(X_{i}\right)$ specifies whether the model is a random effect or a fixed effect model. We test our basic model under this null hypothesis and the Hausman test result is given in Table 3:

$\mathrm{H}_{\mathrm{o}}: \operatorname{Cov}\left(\alpha_{\mathrm{it}}, \mathrm{X}_{\mathrm{it}}\right)=0$ (Random Effect Model)

$\mathrm{H}_{\mathrm{a}}: \operatorname{Cov}\left(\alpha_{\mathrm{it}}, X_{\mathrm{it}}\right) \neq 0$ (Fixed Effect Model)

Table 3: The Hausman specification test result

\begin{tabular}{lll}
\hline Chi-square & Degrees of freedom & Prob. \\
\hline 36.47 & 6 & 0.000 \\
\hline
\end{tabular}

According to test result, the null hypothesis is rejected at any significance level since Prob. value is 0.000 . It is appropriate to carry on with fixed effect model for the rest of the study. The fixed effect model is constructed and then Wooldridge (2002) test, having null hypothesis of no first-order autocorrelation, is applied in order to identify whether serial correlation exists in the error terms in the fixed effect model (Drukker, 2003). The serial correlation in error terms of panel model leads to bias in standard errors and to less efficient coefficients. As to the Wooldridge test result, the F-test statistic $(1,70)$ is calculated as 28.575 and the Prob. value is 0.000 . Therefore, the null hypothesis is rejected at any significance level. The test indentifies a first-order serial correlation between the error terms, implying that a fixed effect model would be misleading with inefficient coefficients. Furthermore, in order to check the existence of heteroscedasticity in residuals of fixed effect model, the modified Wald test for group wise heteroscedasticity, having null hypothesis of homoscedasticity in error terms, is employed (Baum,2001). This test is distributed as chi-square with $\mathrm{N}$ degrees of freedom. The calculated chi-square- test statistics (71) is 18914.59 with a Prob. value of 0.000 . Hence, the homoscedastic variance assumption is violated according to the test result.

Using Ordinary Least Squares (OLS) method while there are heteroscedasticity and serial correlation problems exist in the data, the results would be less efficient. In order to eliminate these problems, the Feasible Generalized Least Square (GLS) Regression is applied for the rest of the study. Differently from the OLS, estimation of $\beta$ coefficients with the Feasible GLS method employs covariance matrix of errors 
$(\Omega)$ so as to increase efficiency and solve the problems resulting from the violation of the assumptions of homoscedastic variance and no serial correlation among error terms (Greene, 2007; Cameron \& Trivedi, 2009). The general model is given as in Equation 3:

$$
y_{i t}=X_{i t} \beta+\epsilon_{i t}
$$

In this form, $\mathrm{i}=1,2, \ldots, \mathrm{m}$ is the number of panels and $\mathrm{t}=1,2, \ldots ., \mathrm{T}_{\mathrm{i}}$ is the number of years in each panel. When applying Feasible GLS, the $\beta$ coefficients are calculated as in Equation 4:

$\widehat{\beta_{G L S}}=\left(X^{\prime} \hat{\Omega}^{-1} X^{-1}\right)^{-1} X^{\prime} \hat{\Omega}^{-1} y(4)$

where $\Omega=\Sigma_{\mathrm{m} \times \mathrm{m}} \otimes \mathrm{I}_{\mathrm{Ti}} \times{ }_{\mathrm{Ti}}$ and the estimator of $\Omega$ is obtained by the help of $\Sigma$. The estimator of $\Sigma(\hat{\Sigma})$ is calcutaled as in Equation 51:

$$
\widehat{\Sigma}_{i, j}=\frac{\hat{\epsilon}_{i}{ }^{\prime} \hat{\epsilon}_{j}}{T}
$$

In order to make the calculations above, the model is firstly estimated by OLS and its residuals are employed. The estimated Feasible GLS regression results are given in Table 4:

\begin{tabular}{|c|c|c|c|c|c|c|}
\hline & (1) & (2) & (3) & (4) & (5) & (6) \\
\hline VARIABLES & CAR & CAR & CAR & CAR & CAR & CAR \\
\hline SIZE & $\begin{array}{l}-0.006^{* * *} \\
(0.002)\end{array}$ & $\begin{array}{l}-0.004^{* * *} \\
(0.001)\end{array}$ & $\begin{array}{l}-0.004^{* * *} \\
(0.001)\end{array}$ & $\begin{array}{l}-0.004^{* * *} \\
(0.001)\end{array}$ & $\begin{array}{l}-0.004^{* * *} \\
(0.001)\end{array}$ & $\begin{array}{l}-0.004^{* * *} \\
(0.001)\end{array}$ \\
\hline ROA & $\begin{array}{l}0.186^{* *} \\
(0.079)\end{array}$ & $\begin{array}{l}0.289^{* * *} \\
(0.085)\end{array}$ & $\begin{array}{l}0.302^{* * *} \\
(0.079)\end{array}$ & $\begin{array}{l}0.292^{* * *} \\
(0.082)\end{array}$ & $\begin{array}{l}0.306^{* * *} \\
(0.079)\end{array}$ & $\begin{array}{l}0.293^{* * *} \\
(0.080)\end{array}$ \\
\hline LEV & $\begin{array}{l}-0.000^{* * *} \\
(0.000)\end{array}$ & $\begin{array}{l}-0.000^{* * *} \\
(0.000)\end{array}$ & $\begin{array}{l}-0.000^{* * *} \\
(0.000)\end{array}$ & $\begin{array}{l}-0.000^{* * *} \\
(0.000)\end{array}$ & $\begin{array}{l}-0.000^{* * *} \\
(0.000)\end{array}$ & $\begin{array}{l}-0.000^{* * *} \\
(0.000)\end{array}$ \\
\hline LQDT & $\begin{array}{l}0.054^{* * *} \\
(0.016)\end{array}$ & $\begin{array}{l}0.038^{* *} \\
(0.017)\end{array}$ & $\begin{array}{l}0.038^{* *} \\
(0.017)\end{array}$ & $\begin{array}{l}0.037 * * \\
(0.017)\end{array}$ & $\begin{array}{l}0.038^{* *} \\
(0.017)\end{array}$ & $\begin{array}{l}0.039 * * \\
(0.017)\end{array}$ \\
\hline NIM & $\begin{array}{l}0.374^{* * *} \\
(0.137)\end{array}$ & $\begin{array}{l}0.081 \\
(0.135)\end{array}$ & & $\begin{array}{l}0.102 \\
(0.139)\end{array}$ & & \\
\hline RISK & $\begin{array}{l}-0.043^{* * *} \\
(0.010)\end{array}$ & $\begin{array}{l}-0.027^{* * *} \\
(0.010)\end{array}$ & $\begin{array}{l}-0.029^{* * *} \\
(0.010)\end{array}$ & $\begin{array}{l}-0.029^{* * *} \\
(0.010)\end{array}$ & $\begin{array}{l}-0.027^{* * *} \\
(0.010)\end{array}$ & $\begin{array}{l}-0.029^{* * *} \\
(0.010)\end{array}$ \\
\hline GDP_G & & $\begin{array}{l}-0.001^{* *} \\
(0.000)\end{array}$ & $\begin{array}{l}-0.001^{* * *} \\
(0.000)\end{array}$ & $\begin{array}{l}-0.001^{* * *} \\
(0.000)\end{array}$ & $\begin{array}{l}-0.000^{*} \\
(0.000)\end{array}$ & $\begin{array}{l}-0.001^{* *} \\
(0.000)\end{array}$ \\
\hline CPI & & $\begin{array}{l}-0.000 \\
(0.001)\end{array}$ & & & $\begin{array}{l}-0.000 \\
(0.000)\end{array}$ & \\
\hline RIR & & $\begin{array}{l}-0.000 \\
(0.000)\end{array}$ & & & & $\begin{array}{l}-0.000 \\
(0.000)\end{array}$ \\
\hline EURO_VOL & & $\begin{array}{l}0.001^{* * * *} \\
(0.000)\end{array}$ & $\begin{array}{l}0.001^{* * *} \\
(0.000)\end{array}$ & $\begin{array}{l}0.001^{* * *} \\
(0.000)\end{array}$ & $\begin{array}{l}0.001^{* * *} \\
(0.000)\end{array}$ & $\begin{array}{l}0.001^{* * *} \\
(0.000)\end{array}$ \\
\hline $\mathrm{COV}$ & & $\begin{array}{l}0.002^{* * *} \\
(0.000)\end{array}$ & $\begin{array}{l}0.002^{* * *} \\
(0.000)\end{array}$ & $\begin{array}{l}0.002^{* * *} \\
(0.000)\end{array}$ & $\begin{array}{l}0.002^{* * *} \\
(0.000)\end{array}$ & $\begin{array}{l}0.002^{* * *} \\
(0.000)\end{array}$ \\
\hline GOV & & $\begin{array}{l}-0.021^{* * *} \\
(0.004)\end{array}$ & $\begin{array}{l}-0.021^{* * *} \\
(0.004)\end{array}$ & $\begin{array}{l}-0.019 * * * \\
(0.004)\end{array}$ & $\begin{array}{l}-0.021^{* * *} \\
(0.004)\end{array}$ & $\begin{array}{l}-0.021^{* * *} \\
(0.004)\end{array}$ \\
\hline CONSTANT & $\begin{array}{l}0.203^{* * *} \\
(0.017)\end{array}$ & $\begin{array}{l}0.173^{* * *} \\
(0.016)\end{array}$ & $\begin{array}{l}0.179^{* * *} \\
(0.015)\end{array}$ & $\begin{array}{l}0.176^{* * *} \\
(0.016)\end{array}$ & $\begin{array}{l}0.176^{* * *} \\
(0.015)\end{array}$ & $\begin{array}{l}0.180^{* * *} \\
(0.015)\end{array}$ \\
\hline Observations & 426 & 426 & 426 & 426 & 426 & 426 \\
\hline Number of bank & 71 & 71 & 71 & 71 & 71 & 71 \\
\hline Wald chi-squared & 121.1 & 276.6 & 246.9 & 248.6 & 265.2 & 252.4 \\
\hline
\end{tabular}

Table4: The Feasible GLS regression results

Notes: Robust standard errors are given in parentheses. ${ }^{* * *}, * * *$ denote $\mathrm{p}<0.01, \mathrm{p}<0.05, \mathrm{p}<0.1$ respectively.

\footnotetext{
${ }^{1}$ The help menu of STATA about fit panel-data by using GLS are also helpful when conducting the feasible GLS analysis (http://www.stata.com/manuals13/xtxtgls.pdf)
} 
Model 1 shows the coefficients of bank-dimensional determinants in our basic model. In Model 2, the coefficients of added environmental factors are also presented. In Model 3, we run the models with only the variables that have significant impacts on CAR in SEE region and this is our final model. The Models from 4 to 6 are given in order to examine whether the insignificant variables may contribute to the final model when they are added into this model one by one. Here, the aim is to observe whether the contributions of these insignificant variables are hidden when they are put together or not. The impact of all variables on CAR is discussed as below.

The coefficients of "size" are calculated as -0.006 and -0.004 in Model 1 and Model 2, respectively. Both are statistically significant at $1 \%$ significance level. The negative sign indicates that as size of the banks increases, the CAR declines. According to the trade-off theory as company size increases, it would be easier to access capital markets with lower transaction costs. The firms with higher profit margins have a better debt servicing capacity and more likely to use higher debt ratio to take advantages of tax shield. Therefore, it is possible to argue that this result is consistent with the trade-off theory. There are different findings as to the sign of size on CAR or leverage on the literature. The sign of "size" on CAR is found as negative and statistically significant by Okuyan (2013) and negative but insignificant Buyuksalvarci and Abdioglu (2011) similar to our findings. Gropp and Heider (2010), on the other hand, analyzed the effect of size, profit and risk on book and market leverage ratios of large US and European banks and found a positive and significant effect of size on both values. On the other hand, Allen et al., (2013) and Juca et al. (2012a) found negative effect of size on leverage. Allen et al., (2013) found that size has a negative but insignificant effect on market leverage but negative and significant effect on book leverage for Thai banks. Juca et al., (2012a) found a negative and significant effect of size on market leverage for North American banks. Finally, Romdhane (2012) found a negative and significant effect of size on capital ratio.

The profitability measured by "ROA" has a positive impact on CAR in our study. Our finding of a positive sign for ROA is consistent with the trade-off theory. The coefficients of ROA are calculated as 0.186 significant at 5\% in Model 1 and 0.289 significant at 1\% in Model 2, respectively. In most cases a high profit margin is an indicator of an efficient firm. High profit margin on assets will increase equity through increase in retained earnings. Our results are similar to Buyuksalvarci and Abdioglu (2011) and Okuyan (2013). On the other hand, Gropp and Heider (2010) found a negative and significant relationship of profit on both book and market leverages. Allen et al., (2013) found that ROA has a negative but insignificant effect on market leverage but positive but insignificant on book leverage for Thai banks. Juca et al. (2012a) found a negative and significant effect of profitability on market leverage for North American banks. The impact of "leverage" on CAR is negative and statistically significant at $1 \%$ level for both Model 1 and Models 2 but the impact is very weak since coefficients are very close zero in both models. The negative sign implies that as leverage increases CAR declines. A higher risk, which could be measured by high degree of leverage, could motivate the managers towards using an even higher debt financing since equity financing would be a costlier alternative. Shareholders in a riskier firm expect relatively higher rate of return from their investment. Buyuksalvarci and Abdioglu (2011) found a negative and significant relationship between leverage and CAR similar to our findings.

The coefficient of "liquidity" is 0.054 and it is statistically significant at $1 \%$ significance level in Model 1 . Similarly, the coefficient is calculated as 0.038 in Model 2 and statistically significant at $5 \%$ significance level. Buyuksalvarci and Abdioglu (2011) found a positive but insignificant relationship between liquidity and CAR The positive sign implies that as banks' liquidity increases CAR increases. A bank with higher liquid assets does not need to borrow and hold a higher degree of equity as predicted by the Pecking Order Theory. As for "net interest margin", the calculated coefficient in Model 1 is 0.374 . This is statistically significant at $1 \%$ significance level. However, when the environmental factors are included in the model, the significance of NIM disappears but its sign remains positive as in Model 1. The study of Kleff and Weber (2008), using net interest income as an indicator of profitability, claims that the banks are likely to raise capital by their accumulated incomes. This positive relationship is consistent with the study of Mili et al. (2014). The coefficients of "risk" are found as - 0.043 in Model 1and -0.027 in Model 2, both are statistically significant at $1 \%$ significance level. The expected sign of risk on CAR is negative on the literature. As risk increases, the CAR ratio is expected to decrease. Equity financing is likely to be a costlier option for banks with higher risk and it is more likely for them to use more debt financing under this situation. As a result, the share of risk weighted assets would increase and in turn it results with a lower CAR for riskier banks. Okuyan (2013) and Bokhari et al. (2012) found a negative and significant relationship between risk and CAR. While Gropp and Heider (2010) found a negative and significant relationship of risk on both book and market leverages, Allen et al. (2013) found positive but insignificant 
effect of risk on market leverage but positive and significant effect of risk on book leverage. Juca et al. (2012a) found a negative and significant effect of risk on market leverage for North American banks. Finally, Romdhane (2012) found a positive and significant effect of risk on capital ratio.

The first factor added in Model 2 is "economic growth" denoted by GDP_G. Its coefficient is calculated as 0.001 and it is statistically significant at $5 \%$ significance level. During the period of strong economic performance, the banks may prefer to work with lower CAR to take advantage of growth opportunities. On the other hand, during recessions, the banks tend to work with higher CAR in order to decrease their risk levels (Bokhari et al., 2012). Hence, the negative relationship between economic growth and CAR is observed. The negative sign is also consistent with the study of Octavia and Brown (2009). Another added factor in Model 2 is "inflation". In this study, the coefficient of inflation has a negative sign and implies a negative effect on CAR but it is almost equal to zero and it is not statistically significant even at $10 \%$ significance level. Williams (2011) argues that high inflationary environment erode the bank capitals, resulting in negative relationship between inflation and CAR, whereas positive relationship is found in the study of Ogere et al. (2013). When it comes to the impact of "real interest rate", its coefficient is detected as negative and is not statistically significant even at $10 \%$. A higher interest rate is a negative development for borrowers as they would likely to have a difficulty paying higher interest bills. Higher interest rates increase the default risk of borrowers; therefore, this may affect the capital ratios of banks in a negative way (Demirguc-Kunt \& Detragiache, 1998).

Another added environmental factor is "Eurozone stock market volatility index". The coefficient of this variable is 0.001 and it is statistically significant at $1 \%$ significance level. During the economic crisis, the market risk tends to increase, so does the volatility index on stock market. Therefore, the banks tend to accumulate more capital in order to handle their fragilities resulting from the volatile market. The coefficient of "Coverage" ratio is found as 0.002 and it is statistically significant at $1 \%$ level. Deposit insurance aims to minimize the banking fragility and reduce bank panics (Demirguc-Kunt \& Detragiache, 1998). In such crisis environment, the authorities in the countries may tend to raise the coverage limits in order to reduce fragility in banking sector. On the other hand, during the crisis time, the banks may show their soundness by retaining high capital adequacy ratios. By considering these together, we expect to find a positive relationship between these two as in our empirical results. However, Gropp and Heider (2010) find a positive relationship between deposit insurance coverage and market leverage; however this impact turns insignificant when the bank-characteristics variables are controlled in the same model.

Finally, the coefficient of "governance" is -0.021 and it is statistically significant at $1 \%$ significance level. In the countries with high rule of law, the creditors are protected so they are inclined to invest more confidently, leading to high leverage in firms (Piaw \& Jais, 2013). In such an environment, the firms are likely to work with less capital. Hence, the expected sign between governance and CAR is negative as we found. We construct Model 3 as a final model including the variables having significant impact on CAR in model 1 and model 2. Only NIM is excluded from the final model since its significance has disappeared when it is combined with environmental factors. In Models from 4 to 6, we add each insignificant variable into the final model one by one. Nevertheless, none of the three insignificant variables created a significant impact on CAR.

\section{Conclusion}

There are legal requirements on banks' capital structure formulating the minimum capital level. Studies from both developed and developing economies show that banks held capital higher than the legal minimum level. These results suggest that there must be factors other than the legal capital requirements determining the capital structure of banks. Factors affecting capital structure in non-financial sectors are reconsidered to explain the capital structure of banks in the related literature. These studies show that factors affecting CAR in non-financial firms also have a significant effect in explaining the CAR of banks. We developed two models in search of factors determining banks' CAR in the SEE region. Size, profitability (ROA), leverage, liquidity, net interest margin (NIM), and risk are used as bank-dimensional explanatory variables in Model 1. Economic growth rate, inflation, real interest rate, Eurozone stock market volatility index, deposit insurance coverage, and governance indicator are added to the original variables to constitute Model 2. The data is analyzed with the Feasible Generalized Least Square (GLS) method. 
Results of our Model 1 are similar to the findings reported in the related finance literature as shown in the previous section. Among the bank-dimensional explanatory variables size, ROA, leverage, liquidity, net interest margin and risk have statistically significant effects in determining CAR for the banks in the SEE region. Among the environmental factors, economic growth rate, Eurozone stock market volatility index, deposit insurance coverage, and governance have statistically significant effects in determining CAR for the banks in the SEE region. While size, leverage, and risk have a negative sign, ROA, liquidity, and net interest margin have a positive sign in Model 1. On the other hand, among the added environmental factors; economic growth rate and governance have a negative sign whereas deposit insurance coverage and Eurozone stock market volatility index have positive effect on CAR. With the exception of Greece, the countries in our study are called transition economies. Their economic reforms and restructuring efforts in the banking sector mostly started back at the end of 1990s and still continue in our present time. They are located next to a well- developed region of the European Union. In relatively small transition economies without fully developed financial markets, we identified significant determinants of CAR in terms of bank specific and environmental factors. It was important to show that factors affecting CAR of developed economies could also explain the CAR of banks in the SEE region.

\section{References}

Acharya, V. V., Engle, R. F. \& Richardson, M. (2012). Capital shortfall: a new approach to ranking and regulating systemic risks. American Economic Review, 102, 59-64.

Altunbas, Y., Santiago, C., Edward, P. M. \& Philip, M. (2007).Examining the Relationships between Capital, Risk and Efficiency in European Banking. European Financial Management, 13(1), 49-70.

Allen, D. E., Napaporn, N. \& Robert, J. P. (2013). The Determinants of Capital Structure: Empirical evidence from Thai Banks. Information Management and Business Review, 5(8), 401-410.

Amidu, M. (2007). Determinants of capital structure of banks in Ghana, an empirical approach. Baltic Journal of Management, 2(1), 67-79.

Amjad, S. \& Tufail, S. (2013). Determinants of Capital Structure: What can be the determinants of capital structure of banking sector of Pakistan?. Proceedings of $3^{\text {rd }}$ International Conference on Business Management (ISBN: 978-969-9368-07-3), 1-27.

Apostolic, R., Christopher, D. \& Peter, W. (2009). Foundations of Banking Risk, New Jersey: John Wiley \& Sons. Inc.

Asarkaya, Y. \& Ozcan, S. (2007). Determinants of Capital Structure in Financial Institutions: The Case of Turkey. Journal of BRSA Banking and Financial Markets, Banking Regulation and Supervision Agency, 1(1), 91-109.

Baltaci, N. \& Ayaydin, H. (2014). Firm, Country and Microeconomic Determinants of Capital Structure: Evidence from Turkish Banking Sector. Emerging Market Journal, 3(3), 46-58.

Baltagi, B. H. (2005). Econometric Analysis of Panel Data, $3^{\text {th }}$ Edition. England: John Wiley \& Sons, Ltd.

Barisitz, S. (2005).Banking in Central and Eastern Europe since the Turn of the Millennium-An Overview of Structural Modernization in Ten Countries. Focus, 2/05, 58-82.

Baum, C. F. (2005). Residual diagnostics for cross section time series regression models. The Stata Journal, 1(1), 101-104.

Bokhari, L. H., Syed, M. A. \& Khurram, S. (2012). Determinants of Capital Adequacy Ratio in Banking Sector: An Empirical Analysis from Pakistan. Academy of Contemporary Research Journal, 2(1), 1-9.

Bonin, J. P. (2004). Banking in the Balkans: the structure of banking sectors in Southeast Europe. Economic Systems, 28, 141-153.

Breusch, T. S. \& Pagan, A. R. (1980). The Lagrange Multiplier Test and Its Applications to Model Specification in Econometrics. Review of Economic Studies, 47, 239-253.

Buyuksalvarci, A. \& Abdioglu, H. (2011). Determinants of capital adequacy ratio in Turkish Banks: A panel data analysis. African Journal of Business Management, 5(27), 11199-11209.

Cameron, A. C. \& Trivedi, P. K. (2009). Microeconometrics Using Stata. Texas: StataCorp LP.

Demirguc, K. A. \& Detragiache, E. (1998).The Determinants of Banking Crisis in Developing and Developed Countries. IMF Staff Paper, 54(1), 81-109.

Demirguc, K. A., Edward, K. \& Laeven, L. (2014). Deposit Insurance Database. The World Bank Policy Research Working Paper, 6934, 1-43.

Drukker, D. M. (2003).Testing for serial correlation in linear panel-data models. The Stata Journal, 3(2), 168-177.

Fauzi, F., Basyith, A. \& Idris, M. (2013). The Determinants of Capital Structure: An Empirical Study on New-Zealand-Listed Firms. Asian Journal of Finance \& Accounting, 5(2), 1-21. 
Frank, M. Z. \& Goyal, V. K. (2005).Trade-off and Pecking Order Theories of Debt. Working Paper. Center for Corporate Governance. Tuck School of Business at Dartmouth, 1-62.

Green, W. H. (2008). Econometric Analysis. New Jersey, Pearson Education Inc.

Gropp, R. \& Heider, F. (2010).The Determinants of Bank Capital Structure. Review of Finance, 14, 587-622.

Hasan, I., Siddique, A. \& Sun, X. (2015). Monitoring the "invisible" hand of market discipline: Capital adequacy revisited. Journal of Banking \& Finance, 50, 475-492.

Hausman, J. A. (1978). Specification Tests in Econometrics. Econometrica, 46, 1251-1271.

Juca, M. N., Sousa, A. F. S. \& Fishlow, A. (2012a). Capital Structure Determinant's of Brazilian and North American Banks. International Journal of Business and Commerce, 1(5), 44-63.

Juca, M. N., Sousa, A. F. S. \& Fishlow, A. (2012b). Capital Structure Determinant's of North American Banks and the Compensation Executive Program-An Empiric Study on the Actual Systemic Crisis. International Journal of Business and Management, 7(17), 3-26.

Kaufmann, D., Kraay A. \& Mastruzzi, M. (2010).The Worldwide Governance Indicators Methodology and Analytical Issues. The World Bank Policy Research Working Paper, 5430, 1-29.

Kim, H. \& Berger Paul, D. (2008). A Comparison of Capital Structure Determinants: The United States and The Republic of Korea. Multinational Business Review, 16(1), 79-100.

Kleff, V. \& Weber, M. (2008). How Do Banks Determine Capital? Empirical Evidence from Research. Germain Economic Review, 9(3), 354-372.

Mamatzakis, E., Staikouras, C. \& Koutsomanoli-Fillipaki, N. (2005). Competition and concentration in the banking sector of the South Eastern European region. Emerging Markets, 6(2), 192-209.

Mathuva, D. M. (2009). Capital Adequacy, Cost Income Ratio and the Performance of Commercial Banks: The Kenyan Scenario. The International Journal of Applied Economics and Finance, 3(2), 35-47.

Mili, M., Sahut, J. M. \& Trimeche, H. (2014). Determinants of the Capital Adequacy Ratio of a Foreign Bank's Subsidiaries: The Role of the Interbank Market and Regulation of Multinational Banks. Ipag Business School Working Paper Series, 366, 1-17.

Modigliani \& Miller. (1958). The Cost of Capital, Corporation finance and the theory of investment. The American Economic Review, 3, 261-297.

Modigliani \& Miller. (1963). Corporate income taxes and the cost of capital: A correction. The American Economic Review, 53(3), 433-443.

Nguyen, H. \& Kayani, Z. (2013). Determinants of banks' capital structure in Asia: A comparison amongst developed and developing countries. Master thesis in Business Administration, Lunds Universitet, 1-53.

Octavia, M. \& Brown, R. (2009). Determinants of Bank Capital Structure in Developing Countries: Regulatory Capital Requirement versus the Standard Determinants of Capital Structure. Journal of Emerging Markets, 2, 50-62.

Ogere, G. A., Peter, Z. \& Inyang, E. E. (2013). Capital Adequacy Ratio and Banking Risks in the Nigeria Money Deposit Banks. Research Journal of Finance and Accounting, 4(17), 17-25.

Okuyan, H. A. (2013). Capital Structure in Turkish Banking System. Ege Academic Review, 13(3), 295-302.

Piaw, L. L. T. \& Jais, M. (2013).The Capital Structure of Malaysian Firms in the Aftermath of Asian Financial Crisis 1997.2 ${ }^{\text {nd }}$ International Conference on Management, Economics and Finance $\left(2^{\text {nd }}\right.$ ICMEF 2013) Proceeding, Malaysia.

Rime, B. (2001). Capital requirements and bank behavior: Empirical evidence for Switzerland. Journal of Banking \& Finance, 25, 789-805.

Romdhane, M. (2012). The Determinants of Banks' Capital Ratio in Developing Countries: Empirical Evidence from Tunisia. Research Journal of Finance and Accounting, 3(1), 35-46.

Saeed, M. M., Gull, A. A. \& Rasheed, M. Y. (2013).Impact of Capital Structure on Banking Performance (A Case Study of Pakistan). Interdisciplinary Journal of Contemporary Research in Business, 4(10), 393-403.

Schaek \& Cihak. (2012). Banking Competition and Capital Ratios. European Financial Management, 18(5), 836-866.

Sharpe, I. G. (1995). Determinants of Capital Structure of Australian Trading Banks. Asia Pacific Journal of Management, 12(2), 97-121.

Staikouras, C., Mamatzakis, E. \& Filippaki, A. K. (2008). Cost efficiency of the banking industry in the South Eastern European region. Int. Fin. Markets, Ins. and Money, 18, 483-497.

Stubos, G. \& Tsikripis, I. (2005). Regional integration challenges in South East Europe: Banking sector trends. Bank of Greece Working Paper, 24, 1-38.

Williams, H. T. (2011). Determinants of capital adequacy in the Banking Sub-Sector of the Nigeria Economy: Efficacy of Camels. (A Model Specification with Co-Integration Analysis). International Journal of Academic Research in Business and Social Sciences, 1(3), 234-248. 